Commonwealth Contributions and British Requirement of Dairy Produce

\author{
By E. Cafstick, United Dairies Ltd., 34 Palace Court, London, $W .2$
}

My task in commenting on this morning's papers, in as far as they dealt with dairy produce, is made easier through the fact that South Africa is unable to export any such foods (van der Post, 1950). Australia, too, does not anticipate any marked increase in her exports of butter and cheese in the next few years (Heywood, 1950). New Zealand and Canada would, therefore, appear to be the two Commonwealth sources from which the United Kingdom may hope to receive increased supplies of these most valuable foods (Hopkirk, 1950; Robertson, 1950). Our Canadian friend this morning told us that Britain does not want to buy food from Canada. This, of course, is not true. We simply cannot find ways and means to pay for half the Canadian food we should like to take. My subsequent remarks are based on the assumption that the financial problem of paying for Canadian and, indeed, other imported foods will be solved.

Statistics reveal that, largely because of the huge net imports of the United Kingdom, the Commonwealth, as a whole, before the war was a net importer of butter, cheese, and concentrated and dried milks. The exigencies of the second world war caused wide variations in the amounts of dairy produce imported from Commonwealth countries. I should like to take this opportunity to pay tribute to Canada for the enormous increase in cheese production which she achieved in 1942, when we were seriously short of high-protein food, and to New Zealand for the uncomplaining way in which she raised to the maximum her production of cheese at the expense of butter in I94I, and changed back again to high butter production in 1942. The apparent tickleness of Britain's demands in 2 successive years, actually due to the shipment of lease-lend cheese from the United States, must have been difficult to explain to New \%ealand farmers and dairy managers.

During the war years milk production increased by $29 \%$ in the United Kingdom, and by $12 \%$ in Canada. In the same period it fell by about $10 \%$ in Australia and New Zealand. Since the war production has gone up in all four countries, but so has the consumption of fresh milk owing to increased population, increased spending power and social welfare schemes such as the National Milk Scheme in this country. The quantity of milk available for manufacture in the Commonwealth is, therefore, well below the prewar level. United Kingdom manufacture, for instance, is only just over half the prewar amount and, though milk production is still more buoyant in Britain than in the rest of the Commonwealth, it is unlikely to reach the prewar figure for some years.

The total imports of dairy produce for the years $1934^{-8}$ and for 1949 are compared in 'Table I. 'The production in the United Kingdom for 1937 and for 1949 is shown in Table 2. The total consumption of dairy produce in the United Kingdom prewar and postwar is set out in Table 3. This last table reveals that we are still receiving only three-fifths of our prewar supply of butter and less than half the amount of canned milks we used before the war. Cheese consumption, however, is greater by $30 \%$ and that of dried milk is nearly five times what it was before. The increased use of cheese arises largely from the extra ration given to heavy workers; the greater consumption of 
dried milk is partly caused by the increased use of this commodity for feeding infants, and the remainder partly replaces the enormous quantities of machine-skimmed, sweetened condensed milk which we used in manufacture.

Table I.* Total imports of dairy produce into the United Kingdom

\begin{tabular}{|c|c|c|}
\hline \multirow[b]{2}{*}{ Milk product } & \multicolumn{2}{|c|}{$\begin{array}{l}\text { Amount imported } \\
\text { per annum }\end{array}$} \\
\hline & $\begin{array}{c}\text { 1934-8 } \\
\text { (Average) }\end{array}$ & 1949 \\
\hline $\begin{array}{l}\text { Butter } \\
\text { Cheese }\end{array}$ & $\begin{array}{l}479 \cdot 8 \\
142 \cdot 4\end{array}$ & $\begin{array}{l}310.9 \\
205.8\end{array}$ \\
\hline $\begin{array}{c}\text { Dried milk, full-cream } \\
\text { skim }\end{array}$ & $5 \cdot 0$ & $\begin{array}{l}10 \cdot 5 \\
24.6\end{array}$ \\
\hline Condensed milk, full-cream, unsweetened & 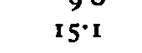 & $13 \cdot 1$ \\
\hline $\begin{array}{l}\text { full cream, sweetened } \\
\text { machine-skimmed, sweetened }\end{array}$ & $\begin{array}{r}5 \cdot x \\
68 \cdot 6\end{array}$ & $\begin{array}{l}23 \cdot 4 \\
21 \cdot 7\end{array}$ \\
\hline
\end{tabular}

- Tables 1,2 and 3 were compiled from dairy produce statistics issued by the Commonwealth Economic Committee and supplied direct by the Ministry of Food.

Table 2.* Production of dairy produce in the United Kingdom

$$
\text { (tons } \times 10^{3} \text { ) }
$$

Milk product

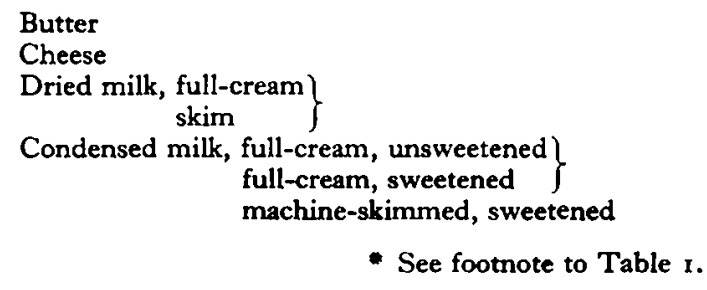

\begin{tabular}{|c|c|}
\hline \multicolumn{2}{|c|}{$\begin{array}{l}\text { Amount produced } \\
\text { per annum }\end{array}$} \\
\hline 1937 & 1949 \\
\hline $\begin{array}{l}19.0 \\
38.0\end{array}$ & $\begin{array}{r}8 \cdot \\
33^{\circ}\end{array}$ \\
\hline 15.0 & 30. \\
\hline 127.2 & $64 \cdot t$ \\
\hline 60.0 & $40^{\circ} \mathrm{C}$ \\
\hline
\end{tabular}

Table $3^{*}$ Consumption of dairy produce in the United Kingdom

\begin{tabular}{|c|c|c|}
\hline \multirow[t]{2}{*}{$\left(\right.$ tons $\left.\times 10^{8}\right)$} & \multicolumn{2}{|c|}{$\begin{array}{l}\text { Amount consumed } \\
\text { per annum }\end{array}$} \\
\hline & $\begin{array}{l}\text { Prewat } \\
\text { years } \\
\text { (Average) }\end{array}$ & 1949 \\
\hline $\left.\begin{array}{l}\text { Butter } \\
\text { Cheese } \\
\text { Dried milk, full-cream } \\
\quad \text { machine skimmed }\end{array}\right\}$ & $\begin{array}{r}498 \cdot 8 \\
180 \cdot 4 \\
29 \cdot 0\end{array}$ & $\begin{aligned} 319 \cdot 3 \\
238 \cdot 4 \\
65 \cdot 1\end{aligned}$ \\
\hline $\begin{array}{l}\text { Condensed milk, full-cream, unsweetened } \\
\text { full cream, sweetened } \\
\text { machine-skimmed, sweetened }\end{array}$ & $\begin{array}{l}147 \cdot 4 \\
128 \cdot 6\end{array}$ & $\begin{array}{r}101 \cdot 1 \\
61 \cdot 7\end{array}$ \\
\hline
\end{tabular}

Of the huge shortage of butter, about 60,000 tons came from countries which are now behind the 'iron curtain' and, as far as can be seen at present, these sources of 
supply are not likely to be restored to us. If the food subsidies are greatly reduced, and dairy produce and other foods are sold at something more nearly approaching the cost of production, I doubt whether the consumption of butter will ever return to its prewar level, but the demand for butter will certainly continue to be greater than the present available supply. It is doubtful whether cheese consumption can be maintained at its present level when meat becomes more plentiful, but the market for supplies of concentrated or dried milks is by no means saturated.

I hope that I have been able to show that the Commonwealth markets for dairy produce in the United Kingdom are capable of considerable expansion, particularly for butter and for concentrated and dried milks. With the wider appreciation of the high nutritive value of milk solids apart from the fat, the quantity of dried milk solids which could usefully be absorbed in this country is well beyond the Commonwealth's capacity to supply. I have in mind particularly a possibility that at some future date dried milk solids may be added to flour for bread making. There are definite signs that both Australia and New Zealand are eager to expand their export of dried separated milk. Unfortunately it necessitates a change in the butter industry from an organization in which only the cream is collected to one in which the whole milk must make the journey to the butter factory, and involving greatly increased needs for transport, heat and power for the production of milk powder.

Few would argue that the cheese market is not saturated with the existing supplies, but I am one who believes that the total consumption could be expanded if the variety of cheeses offered to the housewife was greater. Cheddar is too strong and sharp for many palates which might be tempted by less acid types of cheese such as Gruyère, Edam, Gouda and Port Salut. The demand for Cheshire cheese in the north-west has never been satisfied since before the war. Commonwealth cheese makers might, with considerable ultimate advantage to themselves, examine the possibility of shipping a small proportion of their output as varieties other than Cheddar.

\title{
REFERENCES
}

Heywood, R. H. (1950). Brit. F. Nutrit. 4, 53.

Hopkirk, C. S. M. (1950). Brit. F. Nutrit. 4, 57.

Robertson, J. G. (1950). Brit. F. Nutrit. 4, 49.

van der Post, A. P. (1950). Brit. F. Nutrit. 4, 63.

\section{Commonwealth Contributions and British Requirement of Edible Fats and Oils}

\author{
By C. H. Clarke, c/o Lever Bros. and Unilever Ltd., \\ Unilever House, Blackfriars, London, E.C. 4
}

There appears to be general agreement among those qualified to express an opinion that the world is short of oils and fats. The basis for this view is partly theoretical and derived from calculations of production before the recent world war in comparison with present supplies of oils and fats after allowance has been made for the increase in 